\title{
Integrating Language and Literature: A Text World Theory Approach
}

\author{
La integración de la lengua y la literatura: un acercamiento a la \\ Text World Theory
}

\section{La integració de la llengua i la literatura: un acostament a la Text World Theory}

\author{
Ian Cushing. Brunel University London, UK. ian.cushing@brunel.ac.uk \\ https://orcid.org/0000-0003-1752-1411
}

Marcello Giovanelli. Aston University, UK. m.giovanelli@aston.ac.uk

https://orcid.org/0000-0001-8470-3800

\begin{abstract}
In UK schools, there remains a compartmentalisation of English into 'language' and 'literature', evident in the ways that the subject is taught and examined and in the degrees to which teachers perceive themselves as being either a 'language' or a 'literature' teacher. In this paper, we suggest that an approach informed by cognitive linguistics and cognitive stylistics offers a wealth of affordances to the teacher who wishes to integrate aspects of linguistic and literary studies into their teaching. In particular, we argue that the cognitive discourse grammar Text World Theory provides an accessible and useful set of pedagogical principles. In the two case studies we present, teachers drew upon Text World Theory as a model for thinking about grammar teaching, literature teaching, lesson design, classroom talk and their own identity as teachers of English. The data suggests that this approach may have positive benefits for students engaging in high-level linguistic analysis and in the developing of responses to literature, and for teachers who are responsible for designing lessons and student activities.
\end{abstract}

Key words: stylistics, text World Theory, pedagogy, schools

\section{Resumen}

En las escuelas del Reino Unido, sigue existiendo una compartimentación de la asignatura de inglés en "lengua" y "literatura", evidente en las formas en que se enseña y evalúa la materia, así como en el grado en que el profesorado se percibe a sí mismo como docente de "lengua" o "literatura". En este artículo, sugerimos que un enfoque basado en la lingüística y la estilística cognitivas ofrece una gran cantidad de recursos a quienes desean integrar aspectos de los estudios lingüísticos y literarios en su enseñanza. Argumentamos que, en particular, la gramática cognitiva del discurso Text World Theory proporciona un conjunto accesible y útil de principios pedagógicos, y presentamos dos estudios de casos de investigación en colaboración con docentes que se basaron en la Text World Theory como modelo para pensar sobre la enseñanza de la gramática, la enseñanza de la literatura, el diseño de lecciones o charlas en el aula y su propia identidad como profesores de inglés. Los datos 
sugieren que este enfoque puede tener beneficios positivos para estudiantes que participan en el análisis lingüístico de alto nivel y en el desarrollo de respuestas a la literatura, y así como para docentes que piensan en el diseño de las lecciones y actividades.

Palabras clave: estilística, Text World Theory, pedagogía, escuelas

\section{Resum}

A les escoles del Regne Unit, continua existint una compartimentació de l'assignatura d'anglés en "llengua" i "literatura", evident en les formes en què s'ensenya i s'avalua la matèria, així com en el grau en què el professorat es percep a si mateix com a docent de "llengua" o "literatura". En aquest article, suggerim que un enfocament basat en la lingüística i l'estilística cognitives ofereix una gran quantitat de recursos a aquelles persones que volen integrar aspectes dels estudis lingüístics $\mathrm{i}$ literaris en el seu ensenyament. Argumentem que, en particular, la gramàtica cognitiva del discurs Text World Theory proporciona un conjunt accessible i útil de principis pedagògics, i presentem dos estudis de casos d'investigació en col-laboració amb docents que es van basar en la Text World Theory com a model per pensar sobre l'ensenyament de la gramàtica, l'ensenyament de la literatura, el disseny de lliçons o xerrades a l'aula i la seua pròpia identitat com a professors d'anglès. Les dades suggereixen que aquest enfocament pot tenir beneficis positius per a estudiants que participen en l'anàlisi lingüística d'alt nivell i en el desenvolupament de respostes a la literatura, així com per a docents que pensen en el disseny de lliçons i activitats.

Paraules clau: estilística, Text World Theory, pedagogia, escoles

\section{Introduction}

In schools and universities in the UK, language and literature have often been regarded as discrete subjects and areas of expertise. We see such a polarisation as highly problematic, and argue that teachers can draw on stylistics as a way of perceiving literature and can use tools from linguistics as a way of bringing linguistic and literary studies together in the classroom. The argument for the use of stylistics in schools is in line with a growing movement amongst educators and academic researchers which emphasises the cognitive, social and functional nature of language, as well as valuing the importance of reader-response in studying literature (e.g. Cushing, 2018a, 2018b; Giovanelli, 2016; Myhill, Jones \& Watson, 2012). In this paper, we present and discuss data from research undertaken in UK schools that explores the pedagogical value of the cognitive stylistic framework Text World Theory (Gavins, 2007; Werth, 1999). In doing so, we draw attention to two distinctive but interrelated concerns. First, we argue that stylistics and Text World Theory offer a focused and principled way for teachers to think about the nature of literary response, and a model from which decisions about classroom activities can be made. Second, we suggest that stylistics and Text World Theory offer a wealth of affordances to engage students in meaningful, contextualised language work and to help them bridge the language-literature divide. This study builds on and develops recent work which has explored 
the teachers' potential for drawing on stylistics and Text World Theory in schools (Cushing, 2018a, 2018b; Giovanelli, 2010; 2016; 2017).

This paper is structured in the following way. In section 2, we give a brief overview of the history of and discourses associated with language and literature work in UK schools. In sections 3 and 4, we position Text World Theory as a framework within cognitive linguistics generally and cognitive stylistics more specifically, introducing and outlining its operational parameters and previous pedagogical applications. In sections 5 and 6 , we present two case studies taken from research we have undertaken separately using Text World Theory with teachers in classrooms. We place these together since we believe that they clearly demonstrate how Text World Theory could enhance students' reading and critical skills and could support teachers in designing lesson activities. Finally, some brief discussion and conclusions are presented in section 7. Overall, the main argument of the paper is that stylistics - specifically Text World Theory - offers an accessible and innovative framework that has real benefits for teachers and students, both as a pedagogical grammar and a model of literary reader-response theory.

\section{Language, literature and teachers}

The perceived separation of language and literature is embodied throughout schools and universities in the UK in various forms. For example, in separate GCSE qualifications, the greater proportion of literature than language graduates entering the teaching profession (see Blake \& Shortis, 2010 for statistics), and the way that university departments are often organised into English language and English literature. We take this to be a problematic and reductive understanding of what English studies can and should be.

The perceived separation of language and literature is embodied throughout schools and universities in the UK in various forms. For example, in separate GCSE qualifications, the greater proportion of literature than language graduates entering the teaching profession [...], and the way that university departments are often organised into English language and English literature.
Literature has traditionally held a privileged position in English teaching in UK schools, often viewed as a valuable form of 'cultural capital' (Bourdieu, 1986; Gibbons, 2017; Mathieson, 1975; Shayer, 2013). Perhaps the most explicit and well-known record of this view is found in the Newbolt Report (Board of Education, 1921), where access to the literary canon is presented as a stepping stone to increased intellect, national pride and national cultural identity. Almost 100 years later, the same kind of rhetoric was to be peddled out again, resonating in Michael Gove's discourse on 'tradition' and the championing of exclusively canonical British literature at the heart of the English curriculum (e.g. 
Gove 2010; see Mansworth 2016 for a critique). The division between 'language' and 'literature' can be further perpetuated by the fact that the majority of secondary English teachers entering the profession have largely studied English literature as undergraduates, and therefore, may have covered very little (if any) language or integrated work (e.g. Blake \& Shortis 2010; Cajkler \& Hislam, 2002). The issue of teacher knowledge and preparedness has been a historical problem that has diluted the success of various government initiatives in the past that have attempted to develop language-focused pedagogies in schools (see Giovanelli, 2014, pp. 9-24 for some discussion). In addition, the changing face of initial teacher education in the UK has shifted from university-led to a more school-based system. As a consequence, there is a danger that language work for beginning teachers, historically patchy (Bluett, Cockcroft, Harris, Hodgson and Snapper, 2004), might increase, or even worse, might become non-existent. It may well be that this remains the case for some time, despite the Carter Review (DfE, 2015) which recommends that universities consider introducing bridge modules that connect undergraduate content with that which beginning teachers would be expected to know in order to teach aspects of the secondary curriculum, presumably including some significant linguistic content.

Given this low subject knowledge and inadequate teacher training in linguistics in the UK, it is perhaps not surprising that many English teachers shy away from and feel anxious about integrating what might be seen as 'language' work into the literature classroom. However, these anxieties are often rooted in deep misunderstanding of what 'language work' might be and how this might be developed alongside literary study. Many teachers associate language work with correctness, standards and rules (e.g. Cushing, 2019 forthcoming), with grammar teaching in particular often seen as 'dull' and 'threatening' (Watson, 2012; 2015). In contrast, influential work by Myhill, Jones and Watson (2012) demonstrates that contextualised grammar teaching can have a positive benefit on both student outcomes and their metalinguistic understanding. This kind of pedagogical grammar, which has many parallels with stylistics, has long been a feature of schools in other countries. For example: in Australia in the form of genre theory (see Christie, 2010; Rose \& Martin, 2012); in the USA in the form of rhetorical grammar (see Hancock \& Kolln, 2010), and in Spain, with work on metalinguistic knowledge and writing (Fontich, 2016) - see also Locke (2010) for a range of international perspectives on grammar teaching. Whilst there is no research comparing contextualised grammar pedagogies across different countries, the principles of these pedagogies remain consistent and resonate with the pedagogy we argue for in this paper. 


\section{Cognitive stylistics as a tool for teaching}

The study of language and literature are brought together in the discipline of stylistics, a field that focuses on how texts are produced, received and evaluated, and draws on the most current and relevant insights from linguistics. One sub-field, cognitive stylistics, draws on cognitive linguistics to examine the relationship between texts and literary production and interpretation.

Stylisticians aim to overcome a perceived inherent problem in impressionistic responses to literature by ensuring their analyses are 'rigorous, replicable and retrievable' (Simpson, 2014, 4). Since stylisticians work at the interface of linguistics and literary study, they reject many of the ways that English has been carved up into compartmentalised areas of study, and instead aim to see and develop meaningful connections within the subject as a whole (see Giovanelli, 2014). Indeed, stylisticians have always been interested in the value of a pedagogy based on integration rather than separation (see Hall, 2017 for a developed discussion) which has led to considerable work in applied linguistic approaches to literary study (Pope, 1995; Carter, 1996; Stockwell, 2007).

In this paper, we argue that a pedagogy for teaching literature informed by the cognitive stylistic grammar Text World Theory can be useful for teachers, in light of the contextual, theoretical and practical issues that we have outlined in previous sections. The vignettes that follow in sections 5 and 6 provide concrete examples of how we have worked with teachers in the UK using Text World Theory in our own research. We begin, however, with a more general overview of some of the features and merits of a literary pedagogy in the classroom informed by a cognitive linguistic approach.

We believe that one of the benefits of cognitive linguistics, and consequently cognitive stylistics,

In this paper, we argue that a pedagogy for teaching literature informed by the cognitive stylistic grammar Text World Theory can be useful for teachers, in light of the contextual, theoretical and practical issues that we have outlined in previous sections. for teaching is that it places equal emphasis on the mental and the experiential, highlighting the status of language as a social phenomenon fundamentally shaped by our humanspecific bodies. As Tyler (2012, p. 28) argues, language is always filtered through our 'species-specific neural and anatomical architecture', and therefore, a version of reality is constructed both by our human affordances and our interaction with the social and physical world. Thus, language is viewed not as an autonomous entity that is acquired in a unique manner but, rather, as one of a number of inter-related cognitive functions we use to make sense of 
our surroundings and experiences. Language is learnt through situated use, is largely embodied, and draws on spatial perception to provide a structure for cognition and language itself (for more detailed discussion, see Giovanelli, [2014]).

Using principles from cognitive linguistics as a background for classroom practice has proven to be most effective for learners in L2 contexts both within and outside of the UK. For example, Tyler (2012) outlines how L2 learners developed a much better and quicker understanding of modality when the phenomenon was taught using visual

We believe that one of the benefits of cognitive linguistics, and consequently cognitive stylistics, for teaching is that it places equal emphasis on the mental and the experiential, highlighting the status of language as a social phenomenon

fundamentally shaped by our human-specific bodies representations to model the different types of modal force. These findings have been replicated in studies on prepositions (Evans and Tyler, 2004; Tyler, Mueller \& Ho, 2010), metaphor (Littlemore \& Low, 2006), vocabulary (Boers \& Lindstromberg, 2005), and conditionals (Dolgova Jacobsen, 2018). The scope of cognitive linguistics' influence on L2 can also be seen in the literature that has appeared over the last few years: see for example Robinson and Ellis (2008); Littlemore (2009); Tyler (2012); Holme (2009). There has been, however, limited research in applying some of these principles to L1 contexts in the UK (see Giovanelli, 2014 for an exception) despite the emerging potential of cognitive linguistics within pedagogical stylistics (for example, Cushing, 2018a; Giovanelli, 2010, 2014, 2016, 2017; Giovanelli \& Mason, 2015).

The integrated approach that we are advocating is one where the teacher uses knowledge about language to inform their own classroom practice, their pedagogical decisions and their planning and resources, rather than explicitly teach linguistic content per se. This distinction is neatly captured in Carter's differentiating of 'teaching linguistics' and 'having linguistics as a foundation for classroom language teaching' (1982, p. 8). In a similar way, Halliday (2002) discusses the distinction between grammatics and grammar whereby the former becomes the study of the latter in the same way that linguistics (the study of the phenomenon) is distinguished from language (the phenomenon) (Halliday, 2002, p. 386). Within a pedagogical context, grammatics becomes an enabling framing schema for teachers to use 'grammar to think with' (Halliday, 2002 , p. 416). It offers a contextualised way of informing pedagogical design and allows the teacher to take on the role of researcher in the classroom (Liamkina \& Ryshina-Pankova, 2012), drawing on knowledge about language to develop and reflect on their own practice. We 
therefore argue for a 'cognitive grammatics' (Giovanelli, 2016) in the form of a cognitive pedagogical stylistics that is geared towards serving learners and teachers in the classroom.

\section{Text World Theory}

Text World Theory (Werth, 1999; Gavins, 2007) has important implications for literary readerresponse research because it foregrounds the creative nature of reading and the active,

Meanings are made through an interaction of text and reader: texts project worlds, and readers construct worlds. As a result, meanings are not fixed but dynamic and situational, created by readers who use their prior experiences and knowledge of the actual world autonomous role of the reader. In Text World Theory, participants (writers/readers and speakers/listeners) negotiate rich mental representations of language known as text-worlds, based on the shared and private knowledge between them, and triggered by linguistic content. Meanings are made through an interaction of text and reader: texts project worlds, and readers construct worlds. As a result, meanings are not fixed but dynamic and situational, created by readers who use their prior experiences and knowledge of the actual world. Although Text World Theory stresses the importance of participant knowledge and context, the 'principle of text-drivenness' (Werth, 1999, p. 149) posits that it is the text itself that determines the degree of background knowledge participants draw on when engaging in discourse. It is this principle that marks Text World Theory as a model that can account for how readers access contextual information and knowledge in a rigorous and systematic way.

Text World Theory architecture operates on three embedded conceptual levels: the discourseworld, the text-world and world-switches. Text-world theorists make use of diagrams to show the contents and relationships between these levels (Figure 1).

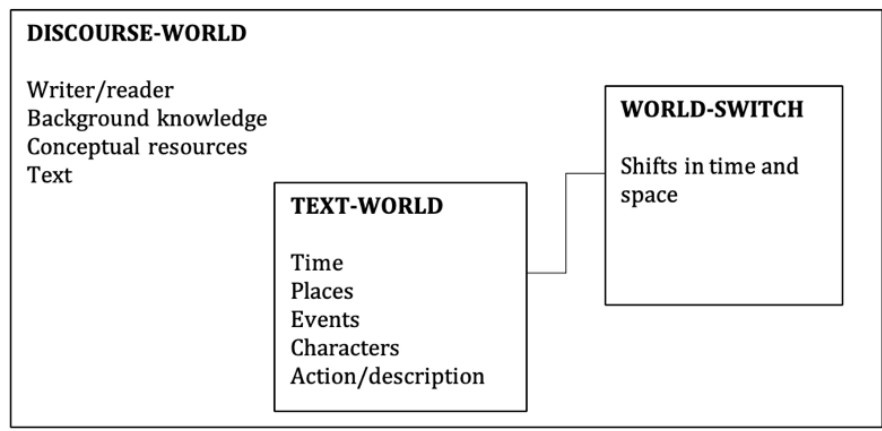

Figure 1. Text World Theory architecture 
The discourse-world is the 'situational context surrounding the speech event itself' (Werth, 1999 , p. 83), the immediate temporal and spatial surroundings in which language event takes place. This level of Text World Theory is concerned with the complexities of situational uses of language and is the entry point to any text-world analysis. Text-worlds are mental representations of language that are negotiated by participants and created through a combination of linguistic content and background knowledge (Werth, 1999, pp. 180-190). Textworlds are always embedded within a discourse-world, indicating the importance of how contextual information shapes language use and interpretation. In terms of linguistic content, text-worlds are constructed from world-building elements and function-advancing propositions. World-builders specify the physical, temporal and spatial properties of a text-world, marked through tensed verbs, prepositions, adverbs, noun phrases, pronouns and instances of deixis. Function-advancers (typically verbs) propel narratives forward, creating dynamism and movement within text-worlds. World-switches occur when linguistic content triggers departures from the original text-world, through a shift in time or space and consequently demands that we shift our attention to a new text-world complete with different deictic parameters. Worldswitches are typically marked by flashbacks/flashforwards, metaphor, negation, imperatives or modalised constructions.

Recent work has seen a growing interest in the application of Text World Theory as a pedagogical tool suitable for use in schools with teachers and young readers. This work has demonstrated how Text World Theory can be actualised by teachers in terms of teaching specific grammatical constructions (Cushing, 2018a), developing meta-reflective skills during reading and drawing on discourse-world knowledge to support literary criticism (Giovanelli, 2016, 2017), tracking worldshifts across literary discourse (Giovanelli, 2010, 2014) and facilitating creative writing (Scott, 2016).

A text-world pedagogy is, therefore, characterised by a number of guiding principles. It emphasises the social, functional and cognitive nature of language, presenting grammar not as a list of abstract rules, but as a series of consciously chosen meaning-making patterns. Such patterns have the capacity to build fictional worlds in the minds of readers, worlds that are fleshed out by the unique background knowledge that a reader brings to a text. Meta-reflective discussion and interpretation of these worlds brings together rigorous linguistic analysis and critical responses to literature. 


\section{Case studies}

In the following sections, we present two case studies that show how we have worked with teachers in the UK to bring Text World Theory into the classroom. In our discussion, we stress the collaborative nature of the research, since our attempts to re-contextualise grammar with a consideration for the local needs of teachers and students meant working closely with teachers in co-designing teaching materials and allowing space and time for personal reflection throughout the process.

\subsection{Students}

This section explores student engagement with literature as a result of a text-world pedagogy. The data is from a series of lessons taught by Rosie, who was in her fifth year of teaching following a degree in English literature. Rosie identified as a 'literature specialist', and this was an important part of her professional identity, given that she had a strong interest in literature and drama. Her interest in Text World Theory stemmed from attending workshops for teachers in stylistics, and collaborating with us as researchers to produce a series of text-world informed lessons on Marianne Moore's poem A Jelly-Fish (Moore, 1959). The poem is show here:

\section{A Jelly-Fish}

Visible, invisible,

a fluctuating charm

an amber-tinctured amethyst

inhabits it, your arm

approaches and it opens

and it closes; you had meant

to catch it and it quivers;

you abandon your intent.

In the poem, world-building elements project a rich text-world, mostly in the form of noun phrases, such as a jelly-fish, fluctuating charm and amber-tinctured amethyst. Functionadvancing propositions, mostly in the form of present tense simple verbs, such as inhabits, approaches, opens and quivers, add a sense of dynamism to the text-world. Readers are invited to further construct a text-world by drawing on their own discourse-world knowledge of oceans and sea creatures. For example, in my own reading, the jelly-fish floats rather mysteriously against an ocean scene full of life, despite such detail not being explicitly present in the text. Furthermore, the use of the second-person pronoun you and the possessive determiner your has the effect of immersing the reader into the text-world, blurring the boundary between 
discourse-world and text-world. The feeling of 'toggling' and movement across world levels is well-documented in Text World Theory, and commonly referred to as edgework (Segal, 1995). Rosie wished to capitalise on such potential effects of the poem, and we worked collaboratively to design the materials, that led to the following set of activities:

1. Students are shown a copy of the poem without the title. Individual readings of the poem and group discussions as to what kind of text-world is triggered, and why.

2. Teacher reveals the title of poem, generating discussion around how and why textworlds have changed because of new information.

3. Students sketch the new text-world and write justifications for this. They compare images in groups and explain the world-building process to each other.

4. Whole class discussion of readerly interpretations and the sense of immersion that the poem evokes, with a focus on the second-person pronoun and possessive determiners.

The following sections explore the process of world-building, and the discussions of reader immersion.

\subsection{World-building}

The title of the poem is a key world-builder, and a neat way of demonstrating the world-building process to students was to only reveal the title after students had discussed what they thought the poem was describing. The responses from students were imaginative and varied: some thought of concrete nouns, such as doors, butterflies and jewels, and some others thought of more abstract concepts, such as hopes and dreams. Some students thought it might be a jelly-fish, but this was not considered as a 'correct' answer by Rosie, in order to resist

The responses from students were imaginative and varied: some thought of concrete nouns, such as doors, butterflies and jewels, and some others thought of more abstract concepts, such as hopes and dreams

During these discussions, it was striking to see a high level of student engagement, with students offering reflective comments on the world-building process. Because students were asked to focus on the kinds of images their own minds were conjuring up, they had the opportunity to reflect on the experience of the reading process itself. After this discussion, the title of the poem, was revealed, with Rosie asking students to consciously reflect on their own text-world construction and modification whilst still legitimatising the personal response that the pedagogy encouraged: 
Rosie:

right (.) the poem is missing its title (.) ok and all of those answers you've just given me are valid because they've come from you as a reader (.) ok let's see the title and think when I do this how your text-worlds change as a result (.) ok ready?

Because new information was gradually added into the discourse, students' responses were geared around their own experiential discourse-world knowledge of oceans and associative memories. For example, Stephen reported his updated text-world in the following way:

Stephen: $\quad$ so now my text-world includes a jelly-fish (.) it's sort of transparent but a slight purple glow to it (.) and has tentacles like kind of ribbons swaying behind it (.) I remember I saw one on holiday just like it (.) and it's kind of coming towards me

Text World Theory handles significant changes to text-world structures as 'world-repair' or 'world-replacement' (Gavins, 2007, pp. 141-142). In these processes, readers update or replace the content of an existing text-world due to new discourse-world information. Text-worlds are rarely static, reflecting the dynamic nature of human communication as participants bring new information into their mental representations.

Stephen's response also highlights the creative nature of reading and the way that linguistic meaning is encyclopedic and experientially based. He clearly does a lot of work in constructing the text-world: him reporting that objects within the text-world are 'sort of transparent' and have a 'slight purple glow to it' is not world-building information explicitly encoded in the text itself; it is information added in via his own discourse-world knowledge relating to lexical domains such as OCEANS and SEA CREATURES. He also recalls personal memories of embodied experiences to help flesh out his own unique text-world, ('remember I saw one on holiday just like it'), foster a meaningful relationship with the text and foreground a personal response that is given 'validity' within the classroom. Similar intertextual comments were highly frequent over the lessons, and proved to be important in helping students to develop personal connections with literary texts. As explained earlier, stylistics and reader-response theories advocate that personal responses are critical part of experiencing literature, often framed as a 'transaction' between text, author and reader (e.g. Rosenblatt, 1978; see also Benton, 1988). Text World Theory advocates a similar position, with the discourse-world acting as a filter for a reader's knowledge, which is then fed into text-world construction.

In the next task, students sketched images to represent their text-worlds and the role that discourse-world knowledge played. The use of images as a teaching tool is well documented (e.g. Benton, 1992; Giovanelli, 2016, 2017), based on the affordances they offer. Images allow 
for the material expression of abstract thoughts, and explicitly show the world-building process in what Giovanelli (2014, p. 43) calls an 'embodied learning activity'. Figure 2 is a visual representation of Stephen's text-world:

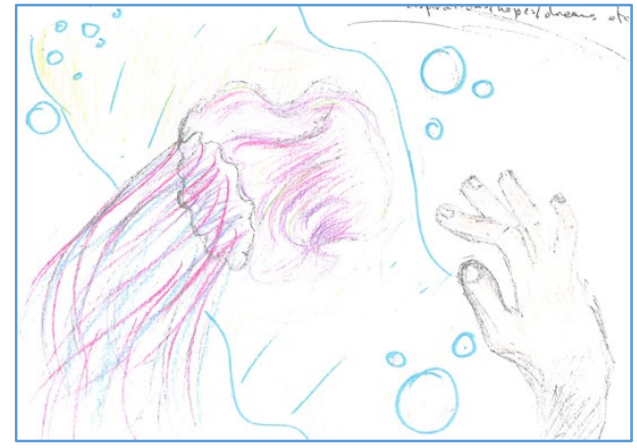

Figure 2. Stephen's visual representation

Stephen's drawing shows a high level of engagement with the text, demonstrating how NP world-builders (jelly-fish; hand; amber-tinctured) fed into the construction of his text-world. The inclusion of his own arm and hand in the drawing reflects the conceptual effect of the secondperson you, inviting Stephen into the text-world as a participant himself and demonstrating an explicit awareness of how writers manipulate perspective and vantage points in language. Traces of his own discourse-world knowledge of oceans are also present, adding extra-textual detail, such as bubbles and underwater light quality, presumably based on his own experiences of the sea as discussed earlier.

The above discussion has shown that students make explicit connections between text and context, assembling this knowledge together in order to make meaningful connections with a literary experience. Framed through the workings of an applied cognitive linguistic pedagogy, this provides students and teachers with a set of metalinguistic terms and pedagogical principles for discussing how texts construct meanings and conceptual effects in the minds of readers.

\subsection{A text-world grammar pedagogy}

The metaphor of READING IS TRANSPORTATION is often used to talk about the experiences of being 'lost' or 'immersed' inside a novel (e.g. Gerrig, 1993). Across the verbal and written discussions of $A$ Jelly-Fish, students referred to this metaphor to describe the feeling of being physically within the fictional world of the poem. Traces of this are evident in Stephen's verbal and visual response above - the clause 'it's kind of coming towards me' and the inclusion of his own arm and hand in Figure 2 suggest that he feels part of the text-world itself. This kind of feeling was echoed by other students in their verbal and visual responses, and the conceptual phenomenon 
of the TRANSPORTATION metaphor triggered an extended discussion across the lessons. For instance, the following exchange between Rosie and Georgie demonstrates students starting to try and account for the conceptual sense of immersion that the poem evoked:

$\begin{array}{ll}\text { Georgie: } & \text { I think (.) it's weird it's like (.) it's like I'm there (.) like I'm in the poem } \\ \text { Rosie: } & \text { ok and why do you think that? how do you feel that? } \\ \text { Georgie: } & \text { it says your arm (.) and you reach out (.) so it's me doing those things } \\ \text { Rosie: } & \text { and so where are you? } \\ \text { Georgie: } & \text { I'm there (.) I'm underwater }\end{array}$

As another example, Megan reported that she felt the text had a physical hold over her. Using negation ('you can't really choose'; 'there's nothing you can do about it'), she indicated that she was being constrained by the immersive power of the text:
Megan: $\quad$ it means you can't really choose what happens like your arm approaches it and you can't really imagine anyone else's
Rosie: $\quad$ so what are you seeing at this point?
Megan: $\quad$ erm well you're put in the position and you're part of the story there's nothing you can do about it

Following discussions about the felt readerly experience of immersion, the teachers asked students to try and account for this in terms of the grammatical structures of the text. This ensured that students' responses were grounded in not just a 'conceptual effect', but in close textual analysis, in accordance with the principles of cognitive stylistics:
Rosie: $\quad$ ok so words that make you feel like you are part of the poem are what? and what types of words are they?
Megan: $\quad$ well this poem talks to me in the second person (.) it uses the word you so it talks to you so that's what the feeling of you in the poem is (.) it's the pronoun that does it I think
Rosie: $\quad$ any others? any other words which make you feel like you are in there?
Megan: $\quad$ your arm (.) it's the your (.) a determiner

The insistence that cognitive stylistics places on combining reader-responses with linguistic detail to account for the reading experience offers a powerful pedagogy for the teaching of literary language in schools. The combination of reader-response theories and cognitive linguistics provides a way of accounting for the conceptual experiences of reading, where 
students employ the use of metalinguistic terminology as an enabling 'tool' to explain their own ideas.

As mentioned in Section 5.1, participants in a discourse world have the potential to feel they are part of a text-world itself. The second-person pronoun is particularly productive in enabling this since it may point to discourse-world reader and text-world enactor at the same time, a phenomenon known as 'double deixis' (Herman, 1994).

Whilst we are not downplaying the importance and value of metalanguage indeed, this is a requirement of doing stylistics - we argue that the use of metalanguage must be grounded in a wider context of reader-response theories. This, we suggest, deepens the students' understanding of grammar and the nature of reading itself.
Crucially, because the concept of immersion had been discussed first, the students' attention was focused on readerly effects and responses to the poem as opposed to grammatical terminology. We believe this order of approaching texts is useful for avoiding simple 'featurespotting', where students are asked to extract grammatical features without exploring the meaning. An alternative way to teach the poem would have been for the teacher to first signal out the importance of the second-person pronoun and then discuss the concepts behind it. However, this would have potentially given emphasis on grammatical meta-language over genuine responses, and would have possibly disrupted what Giovanelli and Mason (2015) call an 'authentic' reading of a text. Instead, the grammatical terminology was introduced only after the students were comfortable with the concept of immersion. Importantly, this was done by the students themselves, with a focus on the connections between the readers' responses and how grammatical choices served to construct meaning. This is representative of what Giovanelli (2014, p. 7-8) calls a 'concept-led' grammar pedagogy, where students are able to explain and account for their literary responses by using supportive and descriptive metalanguage. Whilst we are not downplaying the importance and value of metalanguage - indeed, this is a requirement of doing stylistics - we argue that the use of metalanguage must be grounded in a wider context of reader-response theories. This, we suggest, deepens the students' understanding of grammar and the nature of reading itself.

\section{Teachers}

The following vignette explores the impact taking a Text World Theory approach to the classroom had on one secondary teacher. The teacher in question was Laura, who had been teaching for 3 years, and at the time of the research was teaching in an 11-18 secondary school 
in the south of the UK. Laura had completed an undergraduate degree in English Literature with some limited focus on linguistics and language, and was interested in developing her subject knowledge and expertise.

The researchers and Laura worked with a Year 7 (age 11-12) class developing a text-world pedagogy for the teaching of poetic form, style and point of view in William Carlos Williams' much anthologised poem 'The red wheelbarrow' (Williams, 1923). Full details of the teaching activities can be found in Giovanelli (2016).

\subsection{Re-contextualising Text World Theory and working with teachers}

A key challenge for the researcher working with a practitioner is to avoid the unhelpful practice of simply handing over ideas, whereby the practitioner remains an outsider divorced from the practice of knowledge creation as simply 'the one who spreads other people's butter' (Geer, 1966 , p. 37). Furthermore, the re-contextualisation of any linguistic theory into classroom practice needs careful consideration of how the teacher's expertise in the classroom can be used to transfer rather abstract principles into specific classroom pedagogy and practice. The research principles adhered to the model of researcher and practitioner 'co-construction' (Gravani, 2008) which highlights the role of researchers adopting and validating knowledge in a classroom context and engaging in dissemination in a practical context (Gravani, 2008, p. 657). The researcher's role was to introduce and discuss some of the parameters of the Text World Theory model, to discuss the appropriateness and usefulness of the model for Laura's teaching and to support with any theoretical questions where necessary. As the practitioner and expert, Laura was responsible for developing the teaching resources and lesson delivery. The discussion and analysis that follows is based on field notes and interviews with Laura before and after teaching.

\subsection{Responding to the pedagogy}

This shared work began with Laura reading the leading reference book in the field (Gavins, 2007) and with discussions over the period of six months, both face to face and via email and Skype. During that time, Laura and the researcher also discussed research that explores the Text World Theory as a foundation for classroom activities (e.g. Giovanelli, 2010), as well as the most significant reader-response theories (e.g. Rosenblatt, 1978). She also examined Giovanelli and Mason's arguments (2015), in particular the notions of manufactured and authentic readings and how teachers may divert attention towards specific aspects of a text and privilege certain interpretations through the process of pre-figuring (Giovanelli and Mason, 2015, p. 46). 
Laura was particularly interested in the ways a grammatical framework like Text World Theory can support the teaching of poetry. At the time the research was taking place, GCSE qualifications (taken by 16 year-olds in England) were being reformed and new specifications were being evaluated by teachers in preparation for teaching the following academic year. In Laura's school, the radical changes to the specifications, including an emphasis on canonical literary texts and learning quotations, meant that her department was considering how best to incorporate GCSE texts into the lower school programme of study. Such curriculum reform, and the consequent pressures on teachers, should also be understood in the context of the culture of accountability that exists in secondary schools. As Ball $(2003,216)$ suggests, 'teachers...[may] find their values challenged or displaced by the terrors of performativity' (216) so that 'teaching to the test' becomes the norm. In the context of literature teaching, this may yield more homogenous and less creative responses from students (Benton, 1999; Dymoke, 2002, 2012). Xerri's (2013) interviews with teachers and students show how a vicious circle can operate in classrooms where teachers feel pressurised into providing 'meanings' of poetry, and students are fearful of developing their own responses. Teachers are viewed as 'gatekeepers to meaning' (2013, p. 135). In this pedagogical model, the quest for a 'right answer' might mean that most responses are often concerned with finding information about a poem rather than engaging in the clumsy and uncertain world of shaping and reshaping meanings through reading, discussion and re-reading.In other words, students can view the reading of literature as an 'efferent' rather than an 'aesthetic' experience (Rosenblatt, 1978, p. 23).

\subsection{Using Text World Theory}

It was interesting to observe Laura's thoughts on how working with Text World Theory made her think about teaching poetry, and how the process made her reflect on her identity as a practitioner, particularly as someone from a literature background working in an applied linguistic tradition.

I was interested in how I could learn about the process of reading, to learn about how I could come to teach it better because I don't know how to teach reading. As a secondary school teacher there's so much that we don't know because we expect them to arrive with the skills [from primary school] and they don't unfortunately so that is what interested me. (personal interview)

Laura's comments here reflect on the usefulness of the Text World Theory model in the context of her own status as a practitioner expected to further support the development of independent reading skills in her students. She construes a text-world informed pedagogy as a process and 
further discussion with her highlighted how she valued its central focuses on importance of schematic knowledge in the construction of meaning, and the ways in which she might consider this in her planning and classroom talk. In our discussions, Laura had frequently commented about her anxiety over her approach to the teaching of literary response, particularly with regards to the amount of contextual information she relayed to students. She understood that there was knowledge that students needed to access in order to make sense of poems. At the same time though, she was keen to consider the extent to which a teacher is responsible for introducing this knowledge, and where in the teaching such intervention should occur. For example, Laura's reading and understanding of the types of knowledge the participants would hold in the discourse-world led her to limit the amount of biographical details and notes on imagist poetry she would give to her students so as to allow them to develop their initial responses without being influenced by this information. Later, she included the information into activities together with further details such as an extract from 'Seventy years deep' (Williams 1954), an article in which Williams discussed his influences for 'The red wheelbarrow'. This staging of contextual detail allowed Laura to reflect on her own role as an expert reader with a much richer narrative schema (Mason, 2016) than her students and on the pedagogical implications of this. As Laura noted:

From a teaching point of view drawing on Text World Theory as a way of thinking about planning helped. Less is more in a way and it's how and when you put it [context] in that's important.

Such an approach also drew attention to the resources that students bring to the classroom, and how a text-world approach helped to reassess the assumption that the teacher was the sole authority and legitimator of meaning in discourse about literary texts:

It's good to use with a text like Macbeth where we have a lot of knowledge and they have very little, or so we think. So if you gave them an extract, it would be nice to see what they actually made of it rather than...because I would normally just go straight in and assume that they know nothing and actually when I then read their essays back it's me, it's not them.

Laura also commented on how she felt that Text World Theory's layered architecture offered a very useful platform for teaching narrative point of view. The opening line of 'The red wheelbarrow', 'So much depends' is usually understood by readers as representing direct 
speech of some kind. Since in Text World Theory terms any direct speech represents a worldswitch from an initial text-world, a text-world analysis automatically raises questions about the narrative perspective adopted in both the original world and the world-switch. In her teaching of the poem, Laura was able to draw on this to encourage students to consider perspective in the poem. On the one hand, some students assigned the direct speech to an unnamed character in the fictional world; in this instance, the identifying of an original text-world became a platform for the students to explore a possible backstory, to intervene (Pope, 1995) so as to explore possible gaps, marginalised voices and alternative construals. On the other hand, some students were keen to view the words as the voice of the poet himself and consequently viewed the first line simply as a projecting a text-world that contains the poet-narrator's point of view. These two alternative readings, outlined in Figure 3, allowed Laura to examine some quite complex aspects of point of view and encourage students to explore the hierarchy of perspectives that exist between author, narrator and character.

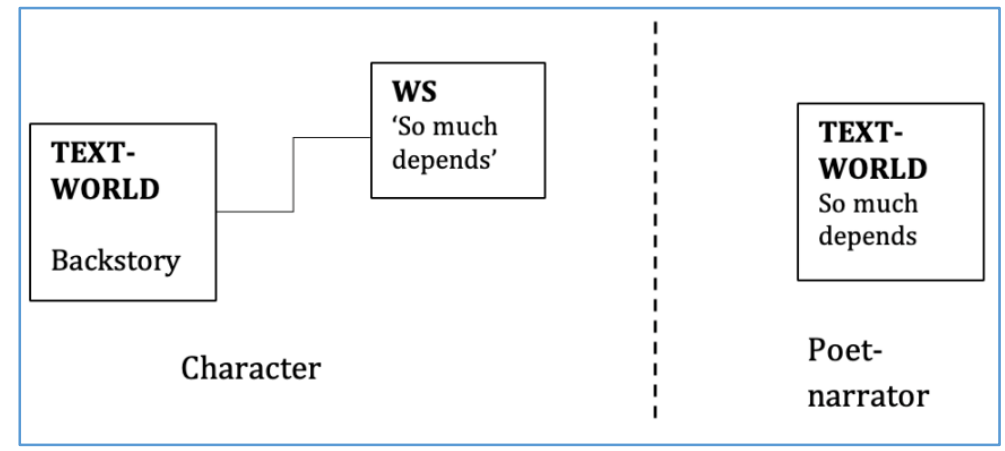

Figure 3. Alternative readings of point of view in 'The red wheelbarrow'

This was particularly useful reflecting on how students' own discourse-world knowledge might have justified assigning point of view: for example, the extent to which students chose to authorise Williams' own story in 'Seventy years deep' to support their decisions. As Laura remarked:

I think it's valuable in teaching terms like narrator, not to teach just the term but to get them to think along the lines of how viewpoint is controlled and expressed in verse. I don't think they'd get it otherwise as easily, it's too much, it's [Text World Theory] a way in.

\subsection{Linguistics and teacher identity}

In initial discussions Laura had expressed some fear and anxiety over her ability to work with a linguistic model on the classroom. Yet one of the driving forces for being involved in the research 
in the first place was to develop her knowledge of linguistics so as to improve her subject knowledge generally. Over the course of her reading, discussing, planning and teaching, Laura had to keep a record of her feelings related to herself as a teacher and following the teaching, she summarised her thoughts:

I've never been very good at language. Literature I find easy but language I always found too scientific and too difficult. It never really computed with me. I was initially worried about what I could do. I needed to read the whole thing [Gavins, 2007] to really get a sense of what I was doing. I tried to cheat a little bit because I felt anxious, can I get away with just reading bits but I couldn't make sense of it so I pushed myself to start at the beginning and that initial fear turned into interest when it started to make sense, by chapter 4 . And now I have a whole new terminology that I feel comfortable using. When I started to think about using it, I couldn't see how the kids would get it but now I can see how this [Text World Theory] has made me think about my teaching and how I support students. It's moved me on, I wouldn't be able to teach some of these things before this work: it [Text World Theory] has given me a tool to think about how I teach and what's useful. I think the process has really helped me understand and be less worried about grammar.

The professional identity of teachers can be viewed as a complex phenomenon that involves a dynamic, constantly evolving sense of self. This is measured against a previous iteration so as to provide a sense of progression (Clarke, 2008; Beauchamp and Thomas, 2009) that is situational in so far as it is informed by external factors (MacLure, 1993). In this instance, Laura's own sense of identity as an English teacher appears to have undergone considerable change, moving from a fear of language work, to an understanding of the need to approach such work carefully and critically, to an understanding of the value of what and how a pedagogy informed by a contemporary cognitive linguistic framework can offer her as a teacher. Laura's reflections thus provide an example of how Text World Theory can work as a cognitive grammatics. 


\section{Conclusion}

Our research suggests that Text World Theory may offer teachers a usable and innovative way of thinking about how language and the nature of literary response works. Although our work focuses on a UK context - which we believe to be important, given the current dynamics in grammar teaching - we see no reason why the approach could not be adopted and examined in other international settings. Whilst the work in this paper is limited to two case studies, the activities and data provide evidence of meaningful, enabling

Our research suggests that Text World Theory may offer teachers a usable and innovative way of thinking about how language and the nature of literary response works. and contextualised work by young children, underpinned by key principles from stylistics. As such, we suggest that this way of thinking about literature teaching and about the integration of the subject more broadly has implications for English. The textworld pedagogy we have examined in this article supports the following broader set of principles that we believe should underpin integrated work in the classroom:

- A students' first exposure to a text should be geared around the primacy of the reading experience.

- Interpretations and responses to texts should be anchored to the text and make close reference to it.

- Grammar should be taught in context, in relation to authentic texts.

- Students should be given the tools to discuss grammatical structures in reference to their meaning-making capacity and their potential to create effects in the minds of readers.

- Metalanguage should be used, but only as a means of enabling a more systematic analysis.

Finally, this article adds to the rapidly growing interest in using Text World Theory as a pedagogical grammar. It also builds on the wealth of work on using cognitive linguistics in various $\mathrm{L} 2$ contexts and applying these principles to the $\mathrm{L} 1$ literature classroom. We believe that the findings and ideas from this research are likely to be generalisable to practitioners who are willing to develop their own linguistic subject knowledge, take a broader, more integrated view of English as a subject, and reframe their professional identities as teachers. 


\section{References}

Ball S. (2003). The teacher's soul and the terrors of performativity. Journal of Education Policy, $18(2), 215-228$

Beauchamp, C., \& Thomas, L. (2009). Understanding teacher identity: an overview of issues in the literature and implications for teacher education. Cambridge Journal of Education, 39(2), 175189.

Benton, M. (1988). Young readers responding to poems. London: Routledge.

Benton, M. (1992) Secondary worlds: literature teaching and the visual arts. Buckingham: Open University Press.

Benton, P. (1999). Unweaving the rainbow: poetry teaching in the secondary school. Oxford Review of Education, 25(2), 521-531.

Bernstein, B. (1996). Pedagogy, symbolic control and identity theory. London: Taylor and Francis.

Blake, J., \& Shortis, T. (2010). Who's prepared to teach school English? The degree level qualifications and preparedness of initial teacher trainees in English. London: Committee for Linguistics in Education.

Bluett, J., Cockcroft, S., Harris, A., Hodgson, J., \& Snapper, G. (2004). Text: message: the future of A level English. Sheffield: National Association for the Teaching of English.

Board of Education. (1921). The teaching of English in England (The Newbolt Report), London: HMSO.

Boers, F., \& Lindstromberg, S. (2005). Finding ways to make phrase-learning feasible: the mnemonic effect of alliteration. System, 33(2), 225-238.

Bourdieu, P. (1986). The forms of capital. In J. Richardson (Ed.), Handbook of theory and research for the sociology of education (pp. 241-258). New York, Greenwood.

Burke, M., Fialho, \& Zyngier, S. (Eds.) (2017). Scientific approaches to literature in learning Environments. Amsterdam. John Benjamins.

Cajkler, W., \& Hislam, J. (2002). Trainee teachers' grammatical knowledge: the tension between public expectation and individual competence. Language Awareness, 11(3), 161-77.

Carter, R. (1982). (Ed.) Linguistics and the teacher. London: Routledge.

Carter, R. (1996). Look both ways before crossing: developments on the language and literature classroom. In R. Carter and J. McRae (Eds.), Language, literature and the learner: creative classroom practice (pp. 1-15). London: Pearson.

Christie, F. (2010). The "grammar wars" in Australia. In T. Locke (Ed.), Beyond the grammar wars (pp. 55-72). London: Routledge.

Clarke, M. (2008). Language teacher identities: co-constructing discourse and community. Clevedon: Multilingual Matters.

Cushing, I. (2018a). 'Suddenly, I am part of the poem': texts as worlds, reader- response and grammar in teaching poetry. English in Education, 52(1), 7-19.

Cushing, I. (2018b). Stylistics goes to school. Language and Literature, 27(4), 271-285.

Cushing, I. (2019, forthcoming). Resources not rulebooks: metaphors for grammar in teachers' metalinguistic discourse. Metaphor and the Social World, 9(2).

DfE. (2015). Carter review of initial teacher training (ITT). London: DfE. 
Dolgova Jacobson, N. (2018). The best of both worlds: combining cognitive linguistics and pedagogic tasks to teach English conditionals. Applied Linguistics, 39(5), 668-693.

Dymoke S. (2002). The dead hand of the exam: the impact of the NEAB anthology on poetry teaching at GCSE. Changing English, 9(1), 85-93.

Dymoke S. (2012). Poetry is an unfamiliar text: locating poetry in Secondary English classrooms in New Zealand and England during a period of curriculum change. Changing English, 19(4), 395410.

Evans, V., \& Tyler, A. (2004). Rethinking English 'prepositions of movement': the case of to and through. Belgian Journal of Linguistics, 18(1), 247-270.

Fontich, X. (2016). L1 grammar instruction and writing: metalinguistic activity as a teaching and writing focus. Language and Linguistics Compass, 10(5): 238-254.

Gavins, J. (2007). Text world theory: an introduction. Edinburgh: Edinburgh University Press.

Geer, B. (1966). Occupational commitment and the teaching profession. The School Review, 74(1), 31-47.

Gerrig, R. (1993). Experiencing narrative worlds: on the psychological activities of reading. Yale: Yale University Press.

Gibbons, S. (2017). English and its teachers. London: Routledge.

Giovanelli, M. (2010). A Text world theory approach to the teaching of poetry. English in Education, 44(3), 214-31.

Giovanelli, M. (2014). Teaching grammar, structure and meaning: exploring theory and practice for post-16 English language teachers. London: Routledge.

Giovanelli, M. (2015). Becoming an A-level English Language teacher: Linguistic knowledge, anxieties and the shifting sense of identity. Language and Education, 29(5), 416-29.

Giovanelli, M. (2016). Text World Theory as cognitive grammatics: a pedagogical application in the secondary classroom', in J. Gavins, \& E. Lahey (Eds.), World-building: discourse in the mind (pp.109-126). London: Bloomsbury Academic.

Giovanelli, M. (2017). Building fictional worlds: visual representations, poetry, readers and cognition. Literacy, 51(1): 26 - 35.

Giovanelli, M., \& Mason, J. (2015). 'Well I don't feel that': schemas, worlds and authentic reading in the classroom. English in Education, 49(1), 41-55.

Gove, M. (2010). All pupils will learn our island story. Speech to the Conservative Party Conference, 5 October 2010.

Gravani, M. (2008). Academics and practitioners: partners in generating knowledge or citizens of two different worlds?. Teaching and Teacher Education, 24, 649-659.

Hall, G. (2017). Literature in language education. (2nd edn.). Basingstoke: Palgrave Macmillan.

Halliday, M. (2002). 'On grammar and grammatics'. In J. Webster (Ed.), On grammar: vol 1 of the collected works of M.A.K. Halliday (pp. 384-417). London: Continuum.

Hancock, C., \& Kolln, M. (2010). Blowin' in the wind: English grammar in United States schools. In T. Locke. (Ed.), Beyond the grammar wars (pp. 21-37). London: Routledge.

Herman, D. (1994). Textual “you” and double deixis in Edna O’Brien's 'A Pagan Place. Style, 28(3), 378-410.

Holme, R. (2009). Cognitive linguistics and language teaching. London: Palgrave Macmillan. 
Liamkina, O. \& Ryshina-Pankova, M. (2012). Grammar dilemma: teaching grammar as a resource for making meaning. The Modern Language Journal, 96(2), 270-289.

Littlemore, J. (2009). Applying cognitive linguistics to second language teaching and learning. London: Palgrave Macmillan.

Littlemore, J., \& Low, G. (2006). Metaphoric competence, second language learning, and communicative language ability. Applied Linguistics, 27(2), 268-294.

Locke, T. (2010). (Ed.) Beyond the grammar wars. London: Routledge

Macken-Horarik, M. (2012). Why school English needs a 'good enough' grammatics (and not more grammar). Changing English, 19(2), 179-194.

MacLure, M. (1993). Arguing for yourself: identity as an organising principle in teachers' jobs and lives. British Educational Research Journal, 19(4), 311-23.

Mansworth, M. (2016). Creative potential within policy: an analysis of the 2013 English Literature curriculum. English in Education, 50(2), 116-129.

Mason J. (2016). Narrative interrelation, intertextuality, and teachers' knowledge about students' reading. In M. Giovanelli \& D. Clayton (Eds.), Knowing about language: linguistics and the secondary English classroom (pp. 162-172). London: Routledge.

Mathieson, M. (1975). The preachers of culture: a study of English and its teachers. London: George Allen and Unwin.

Myhill, D., Jones, S., Lines, H., \& Watson, A. (2012). Re-thinking grammar: the impact of embedded grammar teaching on students' writing and students' metalinguistic understanding. Research Papers in Education, 27(2), 139-166.

Moore, M. (1959). 0 to be a dragon. New York, NY: Viking Press.

Pope, R. (1995). Textual intervention: critical and creative strategies for literary studies. London: Routledge.

Robinson, P. \& Ellis, N.C. (Eds.). (2008). Handbook of cognitive linguistics and second language acquisition. London: Routledge.

Rose, D. \& Martin, J.R. (2012) Learning to write, reading to learn. London: Equinox.

Rosenblatt, L. (1978). The reader, the text and the poem. Southern Illinois University Press.

Segal, E. M. (1995). A cognitive-phenomenological theory of fictional narrative. In J. F. Duchan, G. Bruder \& L. E. Hewitt (Eds.), Deixis in narrative: a cognitive Science perspective (pp. 61-78). Hillsdale, NJ: Lawrence Erlbaum.

Scott, J. (2016). Worlds from words: theories of world-building as a creative writing toolbox. In J. Gavins \& E. Lahey (Eds.), World building: discourse in the mind (pp. 127-145). London: Bloomsbury Academic.

Shayer, D. (2013). The teaching of English in schools 1900-70. London: Routledge.

Simpson, P. (2014). Stylistics: a resource book for students. London: Routledge.

Stockwell, P. (2007). On teaching literature itself. In G. Watson and S. Zyngier (Eds.) Literature and stylistics for language learners: theory and practice (pp. 15-26). Basingstoke: Palgrave Macmillan.

Tyler, A. (2012). Cognitive linguistics and second language learning: theoretical basics and experimental evidence. London: Routledge. 
Tyler, A., Mueller, C., \& Ho, V. (2010). Applying cognitive linguistics to learning the semantics of English to, for and at: an experimental investigation. Vigo International Journal of Applied Linguistics, 8, 181-206.

Watson, H. (2012). Navigating 'the pit of doom': affective responses to teaching grammar. English in Education, 46(1), 21-36.

Watson, H. (2015). Conceptualisations of 'grammar teaching': L1 English teachers' beliefs about teaching grammar for writing, Language Awareness, 24(1), 1-14.

Werth, P. (1999). Text worlds: representing conceptual space in discourse. London: Longman.

Williams, W.C. (1923) Spring and all. Paris: Contact Publishing.

Williams, W. C. (1954). Seventy years deep. Holiday, 16(5), 54-55.

Xerri, D. (2013). Colluding in the 'torture' of poetry: shared beliefs and assessment. English in Education, 47(2), 134-146.

\section{How to cite this paper:}

Cushing, I. \& Giovanelli, M. (2019). Integrating Language and Literature: A Text World Theory Approach. Journal of Literary Education, (2), pp. 199-222. doi: 10.7203/JLE.2.13842 